\title{
Population dynamics of the White Stork Ciconia ciconia in Slovenia BETWEEN I999 AND 2010
}

\section{Populacijska dinamika bele štorklje Ciconia ciconia v Sloveniji med letoma 1999 in 2010}

\author{
DAMiJan Denac \\ DOPPS - BirdLife Slovenia, P.O. Box: 2990, SI-1001 Ljubljana, Slovenia \& National Institute of Biology, Večna pot \\ 111, SI-1000 Ljubljana, Slovenia, e-mail: damijan.denac@dopps.si, damijan.denac@nib.si
}

Between 1999 and 2010, an annual census of the White Stork Ciconia ciconia breeding population was carried out in Slovenia using standardised methods. The Stork's population was concentrated in the NE and SE parts of Slovenia. In the 1999-2010 period, the breeding range of its population in Slovenia expanded in NW direction (the Savska ravan region), in SW direction (the Notranjsko podolje and Pivško podolje regions), but the species also colonized a part between Central and SE Slovenia (Dolenjsko podolje). Between 193 and 240 pairs were breeding during the study period, 209 pairs on average ( $\mathrm{HPa})$. The largest number of breeding pairs was recorded in 2004, the smallest in 2005. During the study period, breeding pairs $(\mathrm{HPa})$ occupied 350 discrete nests in total. Average number of breeding pairs that raised juveniles (HPm) was 161. The highest fecundity was recorded in 2004, when 534 juveniles (JZG) fledged, the lowest in 2006, with only 219 fledged juveniles. On average, 414 juveniles fledged per year. The breeding pairs' (JZa) average breeding success in these 12 years was 2.02, the highest in 2000 (2.41), the lowest in 2006 (1.09). Average breeding success for the successful breeding pairs (JZm) was 2.57. The highest was in 2007 (2.94), the lowest in 2006 (2.07). The largest number of breeding pairs in 2004 and 2008 can be explained by the favourable fecundity in the population in 2000 and 2004, as juveniles become sexually mature at the age of 3-5 years, and at that age they generally return to the breeding grounds for the first time. The lowest number of breeding pairs and poor breeding success in 2005 and 2006 was caused by late arrival of White Storks to the breeding grounds and by unfavourable weather conditions during the breeding period. The pattern of nests placement did not change generally during the last 12 years. The largest proportion of nests was positioned on various kinds of poles (81\%) and on chimneys (18\%). In total, 27 area surveyors and 239 assistants helped in census realisation.

Key words: White Stork, Ciconia ciconia, breeding population, census, Slovenia

Ključne besede: bela štorklja, Ciconia ciconia, gnezditvena populacija, cenzus, Slovenija

\section{Introduction}

At irregular intervals, the White Stork Ciconia ciconia populations have been counted all over the world since 1934. There is no other bird for which statistics on its population trends exist for such a comparably long period of time. Up till now, six international censuses of the White Stork breeding population have been carried out in the years 1934, 1958, 1974, 1984, $1994 / 1995$ and 2004/2005. The data resulting from theses censuses provide an overview of the long term population trend of the White Stork in its overall 
breeding range. The dramatic decline of the population registered up until 1984, when it even became extinct in some countries, was followed by a positive population development in the following 20 years. The world population, which in 1984 was ca. 135,000 breeding pairs $(\mathrm{HPa})$, was estimated to be around 166,000 (HPa) in 1994/1995 (Schulz 1999A \& 1999B). The most prominent increases were noticed for the western population, like Spain, with reasons for the strong increase of the western population mostly attributed to better climatic conditions - less severe droughts - in the wintering areas within western Sahel after the mid-1980s and to development of a wintering population in southern Spain, together with the suite of other factors (TorTOSA et al. 1995, Schulz 1999B, Zwarts et al. 2009). However, in some SE European countries populations were stable or continued declining (SCHULZ 1999B). For the $6^{\text {th }}$ International census 2004/2005, only preliminary results exist, but reveal a further population increase, as the world population was estimated at 230,000 pairs (K.-M. THOMSEN pers. comm.).

The first national White Stork census in Slovenia was carried out in 1965 (ŠošTARIČ 1965). It was repeated in 1979 (Jež 1987) and 1984. In 1984, Slovenia participated in the International White Stork Census (Schulz 1999B) for the first time, and for the second time in the $6^{\text {th }}$ census $2004 / 2005$. Since 1999, the national breeding population has been surveyed annually (DenAC 20OI), using standardized census method and parameters (Schulz I999A, Denac 200I). On a regional scale, two censuses have been carried out annually in Slovenia: the first in NE Slovenia in part of the Drava river lowland, the second in SE Slovenia in the Krka river lowland. Both started in 1989 (ŠTUMBERger I990, HudokLIN I99I) and were integrated into the national census in 1999. In addition, two autecological studies were carried out on the White Stork population in Slovenia using census data. With the first one, we explained density dependent breeding success with intraspecific exploitation competition (DENAC 2006A), whereas the second study showed that weather effect in the reproduction of the White Stork is resource-dependent (DENAC 2006B). In this work we present results of the White Stork censuses carried out between 1999 and 2010.

\section{Study area and methods}

Census method was the same as used during the first annual census in 1999 (Denac 200I). The White Storks' breeding range was divided into regions (mesoregions) according to physiographic regionalisation of Slovenia (Perko 1998). Each region was an independent census unit. In the preparation phase of the census, all surveyors received the regions' maps with marked positions of all known White Storks' nests in their census areas and forms printed for each nest from the central White Stork database for Slovenia. Surveyors were ornithologists and volunteers of DOPPS - BirdLife Slovenia. Generally, the same surveyors carried out the censuses in their corresponding census areas in successive years.

Fieldwork effort was equal in all years. All known nests were visited each year. Besides, villages without nests but with suitable surrounding breeding habitat for the White Stork were thoroughly checked for new nests regularly. Cars were used for transport and binoculars for surveying the breeding parameters. Fieldwork was carried out between 20 Jun and 15 Jul in all years. This is the period just before juvenile White Storks fledge and can be most easily counted from the ground. At each nest, the following breeding parameters were registered: status of the nest or pair $(\mathrm{HPa}, \mathrm{HPx}$, HB2, HB1, HO; see Table 1 for explanation) (Schulz I999A), number of fledged chicks (chicks in the nest during the census were considered as fledged), and nest placement. For new nests, address of the nearest building or location obtained by GPS was recorded. Ground and vegetation under the nests were checked for dead, thrown out chicks. Breeding parameters were obtained by direct observations. As a supporting method, surveyors used interviews with local people to obtain additional data. Data on the number of eggs, number of hatched chicks, ejected chicks and remarks were recorded. Furthermore, in 2004 and 2005 a wider public was informed about the $6^{\text {th }}$ International census and asked through different media to provide us with any data on White Stork nests.

Data were entered in the central White Stork database and processed. If not obtained with GPS, nest coordinates were gained from database of house centroids using addresses of the nests' nearest buildings. Population parameters were analyzed following recommendations by ScHulz (I999B). Single nest visitors (HB1) and pairs visiting nests (HB2) were joined into a single category, nest visitors (HB). The HB1 : HB2 ratio was approximately $1: 1$ in all years. In the breeding success calculation $(\mathrm{JZa})$, we excluded breeding pairs with unknown breeding success: JZa = JZG / ( $\mathrm{HPa}-\mathrm{HPx})$ (SchulZ I999A, Martí 1999), despite the fact that the number of pairs with unknown breeding success was relatively low. We calculated standard deviation for the breeding success (JZa and JZm) (Schulz I999A; see Table 2 
Table 1: The White Stork Ciconia ciconia population parameters in Slovenia between 1999 and 2010

Tabela 1: Populacijski parametri bele štorklje Ciconia ciconia v Sloveniji med letoma 1999 in 2010

\begin{tabular}{|c|c|c|c|c|c|c|c|c|}
\hline Year / Leto & $\mathrm{HPa}$ & $\mathrm{HPm}$ & HPo & $\% \mathrm{HPo}$ & $\mathrm{HPx}$ & $\mathrm{HB}$ & $\mathrm{StD}$ & StDBiol \\
\hline 1999 & 203 & ISI & 50 & 24.6 & 2 & I9 & I.OO & 3.68 \\
\hline 2000 & 197 & 168 & I9 & 9.6 & IO & I5 & 0.97 & 3.57 \\
\hline $200 I$ & 206 & 154 & 44 & $2 \mathrm{I} .4$ & 8 & 16 & I.OI & 3.73 \\
\hline 2002 & 199 & I 53 & 38 & I9.I & 8 & $2 I$ & 0.98 & $3.6 \mathrm{I}$ \\
\hline 2003 & 203 & 162 & 29 & $\mathrm{I} 4 \cdot 3$ & $\mathrm{I} 2$ & $2 \mathrm{I}$ & I.OO & 3.68 \\
\hline 2004 & 240 & 206 & 33 & I3.8 & I & I4 & I.I8 & 4.35 \\
\hline 2005 & 193 & I 28 & 64 & 33.2 & I & 48 & 0.95 & 3.50 \\
\hline 2006 & $2 \mathrm{OI}$ & 106 & 95 & $47 \cdot 3$ & $\mathrm{O}$ & $5 \mathrm{I}$ & 0.99 & 3.64 \\
\hline 2007 & 218 & $\mathrm{I} 77$ & 40 & I8.3 & I & 42 & I.O7 & 3.95 \\
\hline 2008 & 237 & I94 & 43 & I8.I & O & I7 & I.I6 & $4 \cdot 30$ \\
\hline 2009 & 204 & I6I & 43 & 2I.I & $\mathrm{O}$ & $3 \mathrm{I}$ & I.OO & 3.70 \\
\hline 2010 & $20 \mathrm{I}$ & $\mathrm{I} 72$ & 29 & $\mathrm{I} 4.4$ & $\mathrm{O}$ & 37 & 0.99 & 3.64 \\
\hline
\end{tabular}

Abbreviations after ScHulz (I999A) / Okrajšave po ScHULZu (I999A):

$\mathrm{HPa}$ - Pair that occupied a nest for at least 4 weeks during the first half of the breeding season, "breeding pair" / Par, ki je zasedal gnezdo najmanj 4 tedne v prvi polovici gnezditvene sezone, "gnezdeči par" (HPm + HPo + HPx)

$\mathrm{HPm}$ - Pair with fledged young / Par s poletelimi mladiči

HPo - Pair without fledged young that occupied a nest for at least 4 weeks during the first half of the breeding season / Par brez poletelih mladičev, ki je zasedal gnezdo najmanj 4 tedne v prvi polovici gnezditvene sezone

HPx - Pair with unknown breeding success that occupied a nest for at least 4 weeks during the first half of the breeding season / Par $\mathrm{z}$ neznanim gnezditvenim uspehom, ki je zasedal gnezdo najmanj 4 tedne v prvi polovici gnezditvene sezone

HB - Single or two birds (pair) visiting the nest, no ties to the nest / Posamezen osebek ali par obiskuje gnezdo, ni vezi z gnezdom

StD - "Stork density", population density, No. of pairs ( $\mathrm{HPa}$ ) per $100 \mathrm{~km}^{2}$ of a defined surface area (i.e. area of the country) / "Gostota štorkelj”, populacijska gostota; št. parov $(\mathrm{HPa})$ na $100 \mathrm{~km}^{2}$ določene površine (= površina države)

StDBiol - "Biological" population density, No. of pairs $(\mathrm{HPa})$ per $100 \mathrm{~km}^{2}$ of potential feeding habitat / "Biološka" populacijska gostota; št. parov (HPa) na $100 \mathrm{~km}^{2}$ potencialnega prehranjevalnega habitata

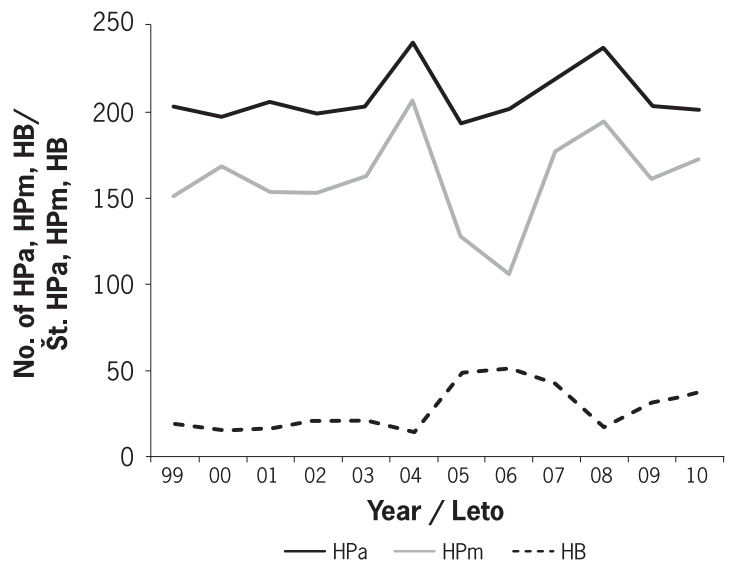

Figure 1: Population dynamics of the White Stork Ciconia ciconia in Slovenia between 1999 and 2010

Slika 1: Populacijska dinamika bele štorklje Ciconia ciconia v Sloveniji med letoma 1999 in 2010

for explanation). We used the surface area of Slovenia $\left(20,272 \mathrm{~km}^{2}\right)$ for the calculation of surface-based population density $(\mathrm{StD})$, whereas the surface area of potential feeding habitats $\left(5,517 \mathrm{~km}^{2}\right)$ was used to calculate biological population density (StDBiol). We selected the following land use categories from land use map of Slovenia (MKGP 2005) as potential feeding habitats: fields and gardens (code 1100), temporary meadows (code 1130), permanent meadows and pastures (code 1300) and wet meadows (code 1321). Selection of potential feeding habitats was based on our own observations and current knowledge about the White Stork feeding habitat's characteristics (SACKL 1987, Alonso et al. I99I, PinOwsKi et al. I986, Dziewiaty 1992, Ożgo \& Bogucki 1999, Moritzi et al. 200I). Population densities (StD and StDBiol) were calculated as the number of breeding pairs $(\mathrm{HPa})$ per $100 \mathrm{~km}^{2}$ surface.

\section{Results}

\subsection{Population distribution and parameters}

A total of 193 to 240 breeding pairs $(\mathrm{HPa})$ were counted in the 1999-2010 breeding seasons, $( \pm$ SD) $209 \pm 15$ pairs on average. The lowest number of breeding pairs was recorded in 2005 and the highest 


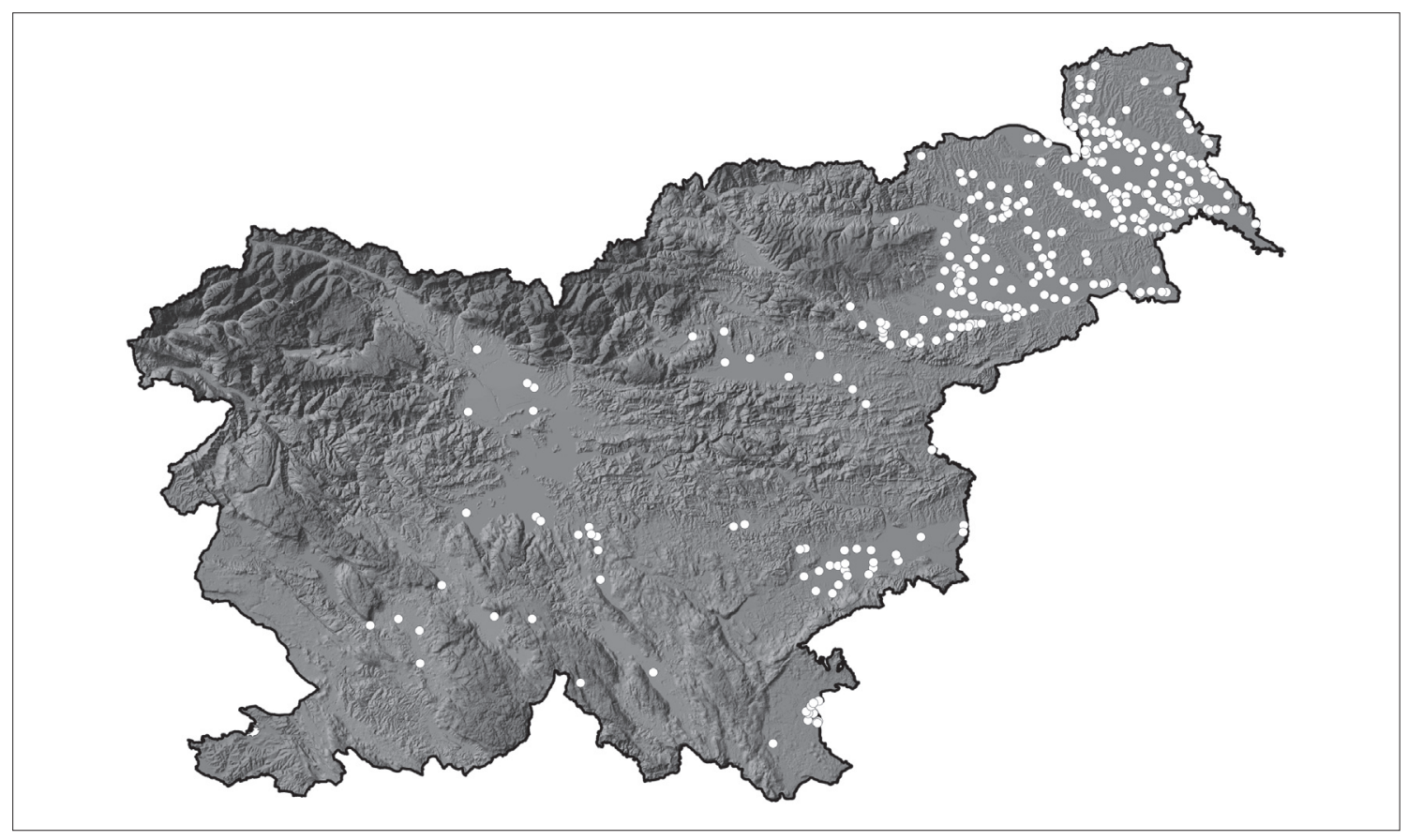

Figure 2: Distribution of all White Stork Ciconia ciconia breeding pairs (HPa) in Slovenia between 1999 and 2010 (N = 350$)$

Slika 2: Razširjenost vseh gnezdečih parov (HPa) bele štorklje Ciconia ciconia v Sloveniji med letoma 1999 in 2010 (N = 350$)$

Table 2: Breeding success of the Slovenian White Stork Ciconia ciconia population between 1999 and 2010 (SD = Standard Deviation)

Tabela 2: Gnezditveni uspeh populacije bele štorklje Ciconia ciconia v Sloveniji med letoma 1999 in 2010 (SD = standardna deviacija)

\begin{tabular}{lccc}
\hline Year / Leto & JZG & JZa \pm SD & JZm \pm SD \\
\hline 1999 & 363 & $\mathrm{I} .8 \mathrm{I} \pm \mathrm{I} .33$ & $2.40 \pm 0.95$ \\
2000 & $45 \mathrm{I}$ & $2.4 \mathrm{I} \pm \mathrm{I} . \mathrm{IO}$ & $2.68 \pm 0.78$ \\
$200 \mathrm{I}$ & 397 & $2.0 \mathrm{I} \pm \mathrm{I} .34$ & $2.58 \pm 0.9 \mathrm{I}$ \\
2002 & $4 \mathrm{I} 7$ & $2.18 \pm \mathrm{I} .35$ & $2.73 \pm 0.88$ \\
2003 & 458 & $2.40 \pm \mathrm{I} .3 \mathrm{O}$ & $2.83 \pm 0.88$ \\
2004 & 534 & $2.23 \pm \mathrm{I} .27$ & $2.59 \pm 0.97$ \\
2005 & 285 & $\mathrm{I} .48 \pm \mathrm{I} .3 \mathrm{O}$ & $2.23 \pm 0.93$ \\
2006 & 219 & $\mathrm{I} .09 \pm \mathrm{I} .23$ & $2.07 \pm 0.93$ \\
2007 & 520 & $2.40 \pm \mathrm{I} .42$ & $2.94 \pm 0.94$ \\
2008 & 527 & $2.22 \pm \mathrm{I} .34$ & $2.72 \pm 0.9 \mathrm{I}$ \\
2009 & $39 \mathrm{I}$ & $\mathrm{I} .92 \pm \mathrm{I} .35$ & $2.43 \pm \mathrm{I} .04$ \\
2010 & $40 \mathrm{I}$ & $2.00 \pm \mathrm{I} . \mathrm{I} 5$ & $2.33 \pm 0.87$ \\
\hline
\end{tabular}

Abbreviations after SCHUlz (1999A) / Okrajšave po SCHulzu (I999A): JZG - Total no. of fledged young / Skupno št. poletelih mladičev

$\mathrm{JZa}$ - Average no. of fledged young per all breeding pairs / Povprečno št. poletelih mladičev vseh gnezdečih parov (JZG / HPa)

$\mathrm{JZm}$ - Average no. of fledged young per all breeding pairs with fledged young/ Povprečno št. poletelih mladičev vseh gnezdečih parov s poletelimi mladiči (JZG / HPm) in 2004 (Table 1, Figure 1, Appendix 1). During the study period, White Stork breeding pairs $(\mathrm{HPa})$ occupied 350 discrete nests in total (Figure 2). On average, $( \pm \mathrm{SD}) 161 \pm 27$ pairs raised juveniles $(\mathrm{HPm})$ in the last 12 years. The largest number of breeding pairs raised their juveniles in 2004, the smallest in 2006. Consequently, the largest number of breeding pairs failed to raise a single juvenile in 2006 (Table 1, Figure 1). The highest fecundity (JZG) was recorded in 2004, when 534 juveniles fledged, the lowest in 2006 with 219 fledged, on average $( \pm$ SD) $414 \pm$ 95 juveniles fledged per year (Table 2, Appendix 2). Average breeding success $( \pm$ SD) for breeding pairs (JZa) in 12 years was $2.02 \pm 1.35$. It was highest in the year $2000(2.41 \pm 1.10)$, and lowest $(1.09 \pm 1.23)$ in 2006 (Table 2, Appendix 3). Average breeding success $( \pm \mathrm{SD})$ for successful breeding pairs $(\mathrm{JZm})$ in 12 years was $2.57 \pm 0.94$. It was highest $(2.94 \pm 0.94)$ in 2007 , and lowest in $2006(2.07 \pm 0.93)$ (Table 2). Number of nest visitors (HB) was in the 15-59 range. The largest number of nest visitors was recorded in 2005 and 2006, the smallest in 2004 (Table 1, Figure 1).

Population was concentrated in the NE part of Slovenia (the Murska and Dravska ravan regions in the Pannonian plains, and the Slovenske gorice, Dravinjske gorice and Goričko regions in the 


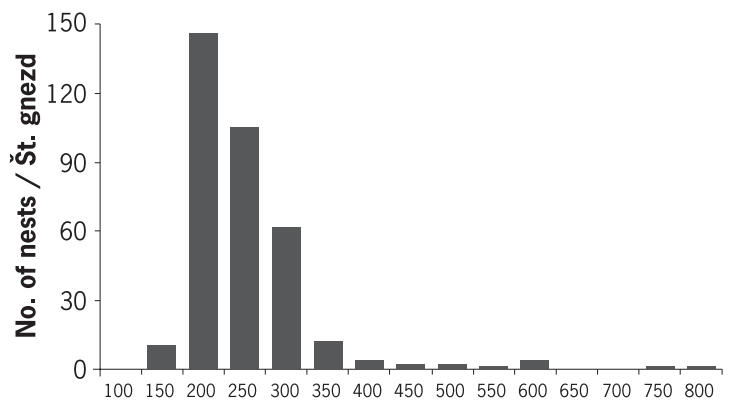

Meters above sea level / Metri nadmorske višine

Figure 3: Altitudinal distribution of all White Stork Ciconia ciconia breeding pairs' (HPa) nests in Slovenia between 1999 and $2010(\mathrm{~N}=350)(100=0-100 \mathrm{~m}, 150=101-150 \mathrm{~m}$, $200=151-200$, etc.)

Slika 3: Višinska razporeditev gnezd vseh gnezdečih parov $(\mathrm{HPa})$ bele štorklje Ciconia ciconia v Sloveniji med letoma 1999 in $2010(\mathrm{~N}=350)(100=0-100 \mathrm{~m}, 150=101-150$ $\mathrm{m}, 200=151-200$ itd.)

Pannonian hills) with considerable numbers in the Pannonian plains in the SE part of Slovenia (the Krška ravan region) and in the Bela krajina and Dolenjsko podolje regions in Dinaric plains (Figure 2, Appendix 1). Smaller disjunct populations were recorded in NW Slovenia in the Savska ravan region, in central Slovenia at Ljubljansko barje, and in SW Slovenia in the Notranjsko podolje and Pivško podolje regions. Altogether, White Storks were recorded to breed in 18 different regions of Slovenia (Appendix 4).

Nests of breeding pairs in $1999-2010(\mathrm{~N}=201)$ were placed at an average altitude $( \pm$ SD) of $226 \pm 77$ $\mathrm{m}$ a.s.l. Lowest nest was at $140 \mathrm{~m}$, and highest at 752 $\mathrm{m}$ a.s.l. (Figure 3).

\subsection{Population dynamics in time and space}

The size of the Slovenian White Stork breeding population has increased in the last 40 years. A population growth of 15\% was recorded in 1979, compared to 1965 (ŠošTarič 1965, Jež 1987). Between 1979 and 1984, the population decreased by $18 \%$. From 1984 to 1999 , the population increased again by $47 \%$. In the $1999-2010$ period, the population size was generally stable, but with the maximum in 2004, when the highest number of breeding White Storks was recorded so far.

Besides population size increase, the population's breeding range expanded, too. In 1965, it was confined to a part of the Pannonian region (Murska and Dravska ravan, Slovenske and Dravinjske Gorice) in NE only. This part can be considered the bird's traditional breeding range. From 1965 to 1999, it extended firstly in the SE direction to the almost entire Pannonian region of Slovenia (the Murska, Dravska and Krška ravan regions and the Goričko, Slovenske and Dravinjske Gorice regions) as well as to the Bela krajina region, and secondly in the NW direction to Ljubljansko barje and to the Alpine plains in NW Slovenia (the Savska and Savinjska ravan regions). After 1999, it expanded its breeding range further in the NW (the Savska ravan region) and SW directions (the Notranjsko podolje, Pivško podolje regions), and colonized a part between Central and SE Slovenia (the Dolenjsko podolje region) (Figure 4).

\subsection{Nest placement}

Nest placements changed during the last 40 years. Proportion of nests on chimneys and trees decreased, while the proportion of nests on different power line poles increased (Figure 5). In 2008, the last breeding in a tree was recorded.

\section{Discussion}

The White Stork population in Slovenia has increased considerably during the last decades. Its population growth from 1984 to 1999 is in agreement with that found for the world population during the $5^{\text {th }}$ international White Stork census (Schulz 1999B). However, the growth of its Slovenian population was higher (47\%) compared to the overall trend for the 1984-1994/1995 period (23\%). Similarly, population growth was the highest compared to the neighbouring countries: Croatia, Hungary, Austria and Italy (ScHulz 1999B), assuming that the Slovenian population in 1999 was representative for 1994/1995.

Between 1999 and 2010, the population was generally stable or slightly increasing but with considerable peaks recorded in years 2004 and 2008. Population growth is generally possible either through immigration or through the population's fecundity, which should be higher than mortality (BEGON et al. 2006, TOME 2006). As we do not have any data on the annual mortality of White Storks in the Slovene population, we cannot reliably infer which of the two population processes in fact caused the growth. Assuming that the annual adult survival probability is 0.7 , and that the survival of young birds until the adult age is 0.5 (KANYAMIBWA et al. 1993), the fecundity of ca. 240 juveniles fledged (JZG) or ca. 1.2 fledged chicks per pair (JZa) would be sufficient to maintain 200 breeding pair population. However, this expert estimate does not account for all the parameters that 


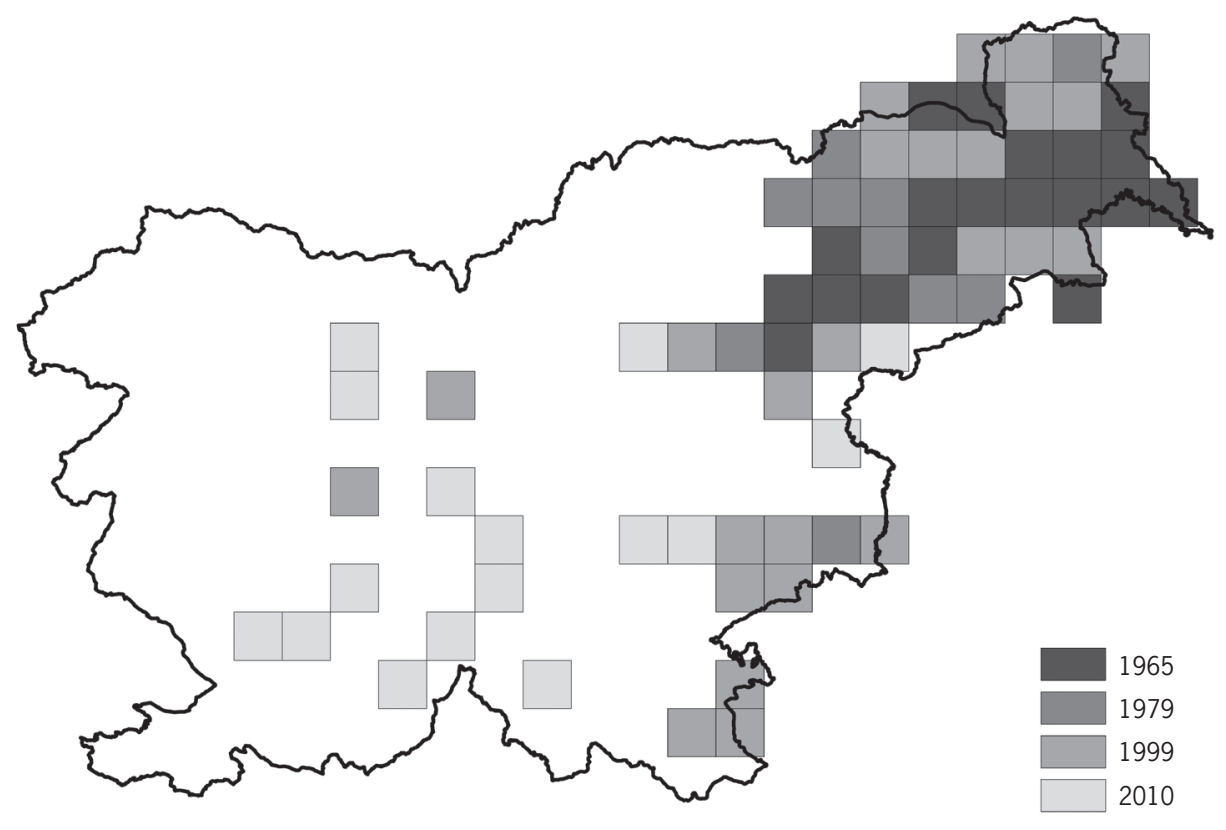

Figure 4: Expansion of the White Stork's Ciconia ciconia breeding range in Slovenia between 1965 and 2010. Distribution in 1965, 1979 and 1999 after ŠoŠTARIČ (1965), JEŽ (1987) and DENAC (2001), respectively. Grey cell = at least one breeding pair (HPa) within the corresponding $10 \mathrm{~km}$ UTM square.

Slika 4: Širjenje gnezditvenega območja bele štorklje Ciconia ciconia v Sloveniji med letoma 1965 in 2010. Razširjenost v letih 1965, 1979 in 1999 je povzeta po ŠošTARIČ (1965), Jež (1987) in DenAC (2001). Siva polja = najmanj en gnezdeči par (HPa) znotraj ustreznega 10 km UTM-kvadrata.

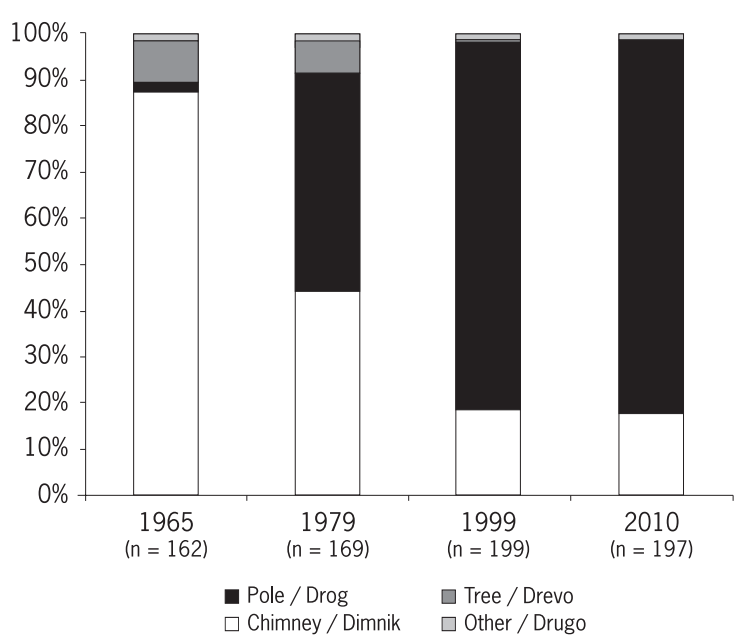

Figure 5: White Stork's Ciconia ciconia nest placements in Slovenia; 1965, 1979 and 1999 data after ŠošTARIČ (1965), JEŽ (1987) and DENAC (2001), respectively

Slika 5: Mesta gnezd bele štorklje Ciconia ciconia v Sloveniji; podatki za 1965, 1979 in 1999 so povzeti po Šoštarič (1965), Jež (1987) in DenAC (2001) should be included in the Population Vulnerability Analysis (PVA). But as the fecundity in 2000 and 2004 was considerably better, and most individuals start breeding 3-5 years old (CrAMP 1977), it is likely that the growth in 2004 and 2008 was caused by particularly good fecundity four years earlier (i.e. in 2000 and 2004). However, in reality open population dynamics is very complex: survival depends on weather (KanyamibWa et al. 1993) and on primary production at the staging areas in Sahel (Schaub et al. 2005), and individuals constantly immigrate and emigrate between populations. In addition, from the findings of ringed birds, evidence exists that individuals from France, Croatia, Germany and Switzerland recently bred in Slovenia (unpublished data of the Slovene Museum of Natural History), confirming immigration to the Slovenian population, although to an unknown extent.

In 2005, the number of breeding pairs considerably decreased. In 2005, storks' arrival was delayed for almost one month on average (median 21 Apr 2005 vs. 27-31 Mar 1999 period in Denac 200I). As a result 
of their late arrival, a significantly higher proportion of storks did not breed and behaved like nest visitors. Because of the late start of the breeding, the fecundity in that year was dramatically low too, as there is a clear relationship between the breeding onset and breeding success. Earlier the breeding onset, the higher the breeding success, and the underlying mechanism for the phenomenon is age-dependent breeding success - older birds return in general earlier and are more successful (Vergara et al. 2007) - and conditionrelated parental quality - heavier females laying more eggs than lighter females (SASvári \& HegYi 200I). The late arrival in 2005 was recorded through the entire breeding range in Europe and was probably caused by severe weather conditions during the spring migration followed by weakened individuals of the breeding population (K.-M. Thomsen pers. comm.). On the contrary, the lowest breeding success recorded during the study, i.e. in 2006, was caused by conditions at the breeding grounds. White Storks returned to the breeding grounds normally. In the second half of May, a week of heavy rains was followed by unusually low temperatures for this period (CEGNAR 2006A \& 2006B). Such conditions occurred in the period of greatest susceptibility of juveniles to the outer conditions as they do not develop thermoregulatory ability till the age of ca. 20 days (Tortosa \& Castro 2003, Jovani \& Tella 2004). After this period, we recorded dramatically larger numbers of dead juveniles thrown out of nests than in previous years (84 in 2006 vs. $24-54$ in years $1999-2010$ without 2006), which is otherwise a normal phenomenon in life-history of the White Stork in such conditions (ToRTOSA \& REDONDO I992). Furthermore, in 2006 several heavy hail storms occurred in NE Slovenia, killing a great number of chicks that survived low temperatures in May. Combination of these two weather effects thus caused the lowest breeding success in the study period.

Full carrying capacity of the traditional breeding range in NE Slovenia was probably achieved, which could explain the expansion of the White Stork's breeding range. As a result of less favourable foraging habitats and higher breeding density in the traditional breeding range, the population's breeding success there is the lowest. In contrast, breeding success is the highest in recently occupied regions in SE Slovenia with more favourable foraging habitats and characteristically lower breeding densities. The representative habitat of the White Stork population in the NE part of Slovenia is composed of large, intensively used arable fields. Storks of the SE population have larger areas of food-rich meadows available. Variability of breeding success between the regions is caused by differences in available food resources. The variability of breeding success between years was explained by weather, specifically by the amount of rainfall in May and temperatures in June. The less the amount of rainfall in May and the higher the temperatures in June, the higher the breeding success. Moreover, weather effect was significant only in the population in the traditional breeding range, which is poorer in the terms of food resources. Food was generally a more important reproductive predictor than weather (DENAC 2006B).

In traditional breeding range with poorer food resources, ecological density influenced the Storks' breeding success. Pairs breeding alone and pairs with one neighbour within their home range most frequently reared three chicks, pairs with two neighbours reared two, whereas pairs with three or four neighbours most frequently failed to raise even a single chick. Intraspecific exploitation competition was the cause for density-dependent breeding success (Denac 2006A).

The trends in nest site selection - reduction of the number of nests in trees and on buildings and the increase of the number of nests on poles - are similar to the trends found elsewhere in Europe (GuZIaK \& JaKubiec 1999, Fulín 1999, Lovászi I999, Rubacha \& JERZAK 2006, TRYANOWSKI et al. 2009). In Slovenia, the trends were mainly caused by changes in architecture and by destruction of traditionally built houses with huge chimneys' platforms commonly used by White Storks. In addition, poles are the only suitable place for nests in the regions where Storks expanded recently.

Acknowledgements: In the first place, I wish to thank all the surveyors for their regular and systematic censusing of a large number of nests - they contributed the core data, and without them the census would not have been possible. They are: Danica Barovič, Dominik Bombek, Luka Božič, Franc Bračko, Katarina Denac, Gregor Domanjko, Dare Fekonja, Andrej Hudoklin, Matjaž Kerček, Dušan Klenovšek, Urška Koce, Janez Kolenko, Tatjana Koren, Branko Koren, Cvetka Marhold, Janez Maroša, Tomaž Mihelič, Bernarda Novak, Matjaž Premzl, Janez Senegačnik, Jakob Smole, Željko Šalamun, Borut Štumberger, Aleš Tomažič, Tadej Trstenjak.

Next, I would like to thank all the surveyors' assistants and all other people who provided us with important data on White Stork breeding: Nataša Adlešič, Ernst Albegger, Mojca Anderlič, Marjeta Arnuš, Janez Balažič, Tilen Basle, Nataša Bavec, Herta Bertalanič, Branka Bezjak, Dejan Bordjan, Marija Bračič, Jožefa Brglez, Marjeta Bukovec, Jurij Cerkvenič, Henrik Ciglič, Tanja Cimerman, Sonja Cvelbar, Rudi Čarni, Barbara Černač, 
Nastja Črepinko, Nastja Črmožnik, Marjan Čuk, Ervin Čukl, Benjamin Denac, Mitja Denac, Jurij Dogša, Gabrijela Dolamič, Smiljana Dovečar, Marjana Farasin, Alojz Fekonja, Elvis Felső, Marko Ferlan, Irena Ferlin, Andrej Figelj, Jernej Figelj, Marija Fištravec, Branko Flisar, Patricija Flisar, Angelca Fras, Franc Fridau, Stane Gabrijel, Maša Gašperin, Anka Glogovšek, Jožef Godec, Tatjana Gregorc, Roza Greif, Jurij Gulič, Helena Gyuran, Mirjana Halas, Franc Hameršak, Jurij Hanžel, Anita Hari, Mateja Hari, Vojko Havliček, Mira Hergan, Anica Hlebec, Štefan Holcman, Dejan Horvat, Gašper Horvat, Srečko Horvat, Teodor Horvat, Peter Idzig, Anica Ilar, Mira Ivanovič, Silva Izlakar, Ana Jaklič, Jože Jančar, Žan Janežič, Manca Jereb, Nada Jesenko Kiauta, Lara Jogan, Andreja Jurša, Andreja Juterša, Andrej Kapla, Sani Katani, Aleš Kavčič, Marija Kavčič, Leon Kebe, Edina Kepe, Tjaša Kerček, Mojca Klemenčič, Ivan Kljun, Boris Kočevar, Jure Kočevar, Jože Kočiš, Miran Kolednik, Matej Kolenko, Simon Komar, Jurij Koren, Bernarda Koroša, Luka Korošec, Marija Kos, Klavdija Kosec, Alojz Kovač, Matej Kovač, Alenka Kramar, Darko Kramar, Katka Kranjc, Zvonko Križanič, Natalija Krušič, Andrej Kržan, Anita Kšela, Tadej Kugler, Benjamin Kuhar, Alojz Kurbus, Jana Kus Veenvliet, Danica Kušter, Vesna Lamot, Nikolaj Lapuh, Jože Leskovar, Terezija Leskovar, Jurij Leskovšek, Katja Lovrenko, Martina Luzar, Monika Maček, Roman Maguša, Nevenka Maltarič, Ivanka Malus, Maja Marčič, Jurij Marhold, Rado Marhold, Aljoša Markovič, Janko Markovič, Katja Markovič, Ambrož Maroša, Štefanija Masten, Klara Megla, Borut Mekinda, Marija Mekiš, Andreja Mes, Barbara Mihelič, Liza Mraz, Matej Muršec, Boris Nabergoj, Brigita Nahberger, Jure Novak, Nina Orehar, Leon Pavalec, Andreja Pavlinjek, Petra Pavlovčič, Rok Pernat, Milena Pernek, Mirko Perušek, Anton Petovar, Alenka Petrinjak, Franc Pihler, Tadej Pipan, Barbara Pislak, Borut Pittner, Alen Ploj, Miha Podlogar, Slavko Polak, Mateja Polutnik, Janja Potrč, Robert Potrč, Marija Primožič, Aleksander Pritekelj, Franc Puklavec, Cirila Purg, Andreja Radetič, Petra Radolič, Tina Rastar, Petra Rems, Žiga Repotočnik, Ivan Resnik, Rok Rozman, Ksenja Rudolf, Jože Sagadin, Franc Sarka, Primož Sedminek, Evgen Sever, Ludvik Sever, Marta Sever, Terezija Sever, Mirko Silan, Janja Simončič, Jože Sinic, Klarisa Sipoš, Maja Slak, Vojko Stolnik, Marjana Strajnar, Slavko Strman, Denis Strnad, Tom Strojnik, Renata Šadl, Nataša Šalaja, Gregor Šalamun, Dominik Šandor, Valentina Šandor, Blaž Šegula, Dare Šere, Anton Šešerko, Franc Šeško, Katja Šinko, Nadja Škafar, Mojca Škrget, Ljubica Šmit, Anja Šolar Levar, Katja Štraus, Greta Štumberger, Tanja Šumrada, Mimica Šuštarič, Michael Tifenbach, Petra Topolnik, Mirko Tramser, Marjan Trobec, Peter Trontelj, Vladka Tucovič, Ana Turkuš, Rok Tuš, Sandra Ulen, Janko Urbanek, Rozalija Vajdič, Dragica Vek, Denis Vengust, Jani Vidmar, Vlado Vindar, Erik Vodenik, Jan Vodovnik, Ivanka Voga, Ana Vogrinčič, Janez Voršič, Al Vrezec, Petra Vrh Vrezec, Davorin Vrhovnik,
Simon Vugrinec, David Vujinovič, Ivan Zadravec, Matej Zadravec, Barbara Zakšek, Roman Zavratnik, Karel Zelič, Janez Zelnik, Simona Zver, Branko Žel, Julija Železen, Jan Žibert, Feliks Žitek, Leopold Župančič.

All the surveyors, assistants and other people collaborated in the White Stork census as volunteers. The greater part of the censuses in the years 2000 (Velika Polana), 2003 (Trnovska vas) and 2004 (Ptuj) was carried out within the scope of DOPPS - BirdLife Slovenia ornithological research camps for young ornithologists. Since 2004, the census in IBAs/SPAs is part of a National Monitoring Scheme of qualifying bird species and is supported by the Slovenian Ministry of the Environment and Spatial Planning. During the last 12 years, several endangered nests have been protected and saved by colleagues from the Institute of the Republic of Slovenia for Nature Conservation (ZRSVN), and therefore I dedicate the article to them, especially to Mr. Janko Urbanek.

\section{Povzetek}

Med letoma 1999 in 2010 smo na območju Slovenije opravili vsakoletni cenzus gnezditvene populacije bele štorklje Ciconia ciconia. Vse cenzuse smo izvedli skladno $\mathrm{z}$ mednarodno metodo popisovanja. Jedro populacije bele štorklje je v SV in JV Sloveniji. Od leta 1999 do leta 2010 se je gnezditveno območje bele štorklje v Sloveniji iz tradicionalnih gnezdišč razširilo v SZ (Savska ravan) in JZ smeri (Notranjsko in Pivško podolje), bela štorklja pa je kolonizirala tudi del Dolenjskega podolja med osrednjo in JV Slovenijo. $\mathrm{V}$ popisnem obdobju je gnezdilo med 193 in 240 parov $(\mathrm{HPa}), \mathrm{v}$ povprečju 209. Največje število parov je gnezdilo leta 2004, najmanjše leta 2005. Skupno so v tem obdobju gnezdeči pari (HPa) zasedli 350 različnih gnezd. Povprečno število uspešnih parov - parov, ki so speljali mladiče (HPm) - je bilo 161 . Največjo rodnost populacije (JZG) smo ugotovili v letu 2004, ko je poletelo 534 mladičev, najmanjšo pa leta 2006, takrat je poletelo 219 mladičev. V povprečju je poletelo 414 mladičev letno. Povprečni gnezditveni uspeh gnezdečih parov (JZa) je bil 2,02, največji je bil leta 2000 (2,41), najmanjši leta $2006(1,09)$. Povprečni gnezditveni uspeh uspešnih parov (JZm) je bil 2,57, največji je bil leta 2007 (2,94), najmanjši pa leta 2006 $(2,07)$. Veliko število gnezdečih parov leta 2004 in 2008 lahko razložimo z dobro rodnostjo v letih 2000 in 2004, saj mladiči spolno dozorijo med 3-5 leti in se v tej starosti praviloma prvič vrnejo s prezimovališč na območja gnezdenja. Mesta gnezd se v zadnjih 12 letih v glavnem niso spremenila. Največ gnezd (81\%) je bilo na različnih drogovih, večinoma električne napeljave, 
sledila so gnezda na dimnikih (18\%). Pri izvedbi cenzusa je sodelovalo 27 območnih popisovalcev in 239 pomočnikov oziroma informatorjev.

\section{References}

Alonso, J.C., Alonso, J.A. \& Carrascal, L.M. (I99i): Habitat selection by foraging White Storks, Ciconia ciconia, during the breeding period. - Canadian Journal of Zoology 69: 1957-1962.

Begon, M., Townsend, C.R. \& Harper, J.L. (2006): Ecology. From Individuals to Ecosystems. - Blackwell Publishing, Oxford.

Cegnar, T. (2006A): Podnebne razmere v maju 2006. Mesečni bilten Agencije RS za okolje 8 (5): 3-20.

Cegnar, T. (2006B): Podnebne razmere v juniju 2006. Mesečni bilten Agencije RS za okolje 8 (6): 3-22.

Cramp, S. (ed.) (I977): Handbook of the birds of Europe, the Middle East and North Africa. The birds of the eastern Palearctic. Vol. 1. Ostrich to Ducks. - Oxford University Press, Oxford.

Denac, D. (200I): Gnezditvena biologija, fenologija in razširjenost bele štorklje Ciconia ciconia v Sloveniji. Acrocephalus 22 (106/107): 89-103.

Denac, D. (2006A): Intraspecific Exploitation Competition as Cause for Density Dependent Breeding Success in the White Stork. - Waterbirds 29 (3): 391-394.

Denac, D. (2006в): Resource-dependent weather effect in the reproduction of the White Stork Ciconia ciconia. Ardea 94 (2): 232-240.

Dziewiaty, K. (I992): Nahrungsökologische Untersuchungen am Weißstorch Ciconia ciconia in der Dannenberger Elbmarsch (Niedersachsen). - Vogelwelt 113 (3): 133-144.

Fulín, M. (1999): The White Stork in Slovakia in 1994 and 1995. pp. 199-202 In: Schulz, H. (ed.): Weißstorch im Aufwind? - White Storks on the up? Proceedings International Symposium on the White Stork, 26-29 September 1996, Hamburg. - NABU (Naturschutzbund Deutschland), Bonn.

Guziak, R. \& Jakubiec, Z. (I999): Der Weißstorch Ciconia ciconia in Polen im Jahr 1995 - Verbreitung, Bestand und Schutzstatus. pp. 171-187 In: Schulz, H. (ed.): Weißstorch im Aufwind? - White Storks on the up? Proceedings International Symposium on the White Stork, 26-29 September 1996, Hamburg. - NABU (Naturschutzbund Deutschland), Bonn.

Hudoklin, A. (I99I): Bela štorklja Ciconia ciconia na jugovzhodnem Dolenjskem. - Acrocephalus 12 (47): 24-27.

Jež, M. (1987): Bela štorklja (Ciconia ciconia L.) v Sloveniji v letu 1979. - Varstvo narave 13: 79-92.

Jovani, R. \& Tella, J.L. (2004): Age-related environmental sensitivity and weather mediated nestling mortality in white storks Ciconia ciconia. - Ecography 27 (5): 611-618.

Kanyamibwa, S., Bairlein, F. \& Schierer, A. (I993): Comparison of survival rates between populations of the White Stork Ciconia ciconia in Central Europe. - Ornis Scandinavica 24: 297-302.
LovÁszi, P. (I999): Conservation status of the White Stork in Hungary. pp. 203-211 In: Schulz, H. (ed.): Weißstorch im Aufwind? - White Storks on the up? Proceedings International Symposium on the White Stork, 26-29 September 1996, Hamburg. - NABU (Naturschutzbund Deutschland), Bonn.

Martí, R. (1999): Results of the $5^{\text {th }}$ International White Stork Census (1994) in Spain. pp. 61-68 In: Schulz, H. (ed.): Weißstorch im Aufwind? - White Storks on the up? Proceedings International Symposium on the White Stork, 26-29 September 1996, Hamburg. - NABU (Naturschutzbund Deutschland), Bonn.

MKGP (2005): Land-use map. - Ministry of Agriculture, Forestry and Food, Ljubljana.

Moritzi, M., Maumary, L., Schmid, D., Steiner, I., Vallotton, L., Spaar, R. \& Biber, O. (200I): Time budget, habitat use and breeding success of White Storks Ciconia ciconia under variable foraging conditions during the breeding season in Switzerland. - Ardea 89 (3): $457-470$.

Ożgo, M. \& Bogucki, Z. (I999): Home range and intersexual differences in the foraging habitat use of a White Stork (Ciconia ciconia) breeding pair. pp. 481-492 In: Schulz, H. (ed.): Weißstorch im Aufwind? - White Storks on the up? Proceedings International Symposium on the White Stork, 26-29 September 1996, Hamburg. - NABU (Naturschutzbund Deutschland), Bonn.

Perko, D. (I998): Pokrajine. pp. 120-125 In: Fridl, J., Kladnik, D., Orožen Adamič, M. \& Perko, D. (eds.): Geografski atlas Slovenije: Država v prostoru in času. DZS, Ljubljana.

Pinowski, J., Pinowska, B., de Graaf, R. \& Visser, J. (1986): Der Einfluß des Milieus auf die NahrungsEffektivität des Weißstorchs (Ciconia ciconia L.). Beihefte zu den Veröffentlichungen für Naturschutz und Landschaftspflege in Baden-Württemberg 43: 243-252.

Rubacha, S. \& JeRZAK, L. (2006): Changes in the White Stork Ciconia ciconia population number, density and breeding places in Zielona Góra region 1926-2004. pp. 47-54 In: Tryanowski, P., Sparks, T.H. \& Jerzak, L. (eds.): The White Stork in Poland: studies in biology, ecology and conservation. - Bogucki Wydawnictwo Naukowe, Poznań.

SACKL, P. (1987): Über saisonale und regionale Unterscheide in der Ernährung und Nahrungswahl des Weißstorches (Ciconia c. ciconia) im Verlauf der Brutperiode. - Egretta 30 (2): 49-79.

Sasvári, L. \& Hegyi, Z. (200I): Condition-dependent parental effort and reproductive performance in the White Stork Ciconia ciconia. - Ardea 89 (2): 281-291.

Schaub, M., Kania, W. \& Köppen, U. (2005): Variation of primary production during winter induces synchrony in survival rates in migratory white storks Ciconia ciconia. Journal of Animal Ecology 74: 656-666.

Schulz, H. (I999A): The $5^{\text {th }}$ International White Stork Census 1994/95 - Preparation, realisation and methods. pp. 39-48 In: Schulz, H. (ed.): Weißstorch im Aufwind? - White Storks on the up? Proceedings International Symposium on the White Stork, 26-29 September 1996, Hamburg. - NABU (Naturschutzbund Deutschland), Bonn. 
Schulz, H. (1999в): The world population of the White Stork (Ciconia ciconia) - Results of the $5^{\text {th }}$ International White Stork Census 1994/95. pp. 351-365 In: Schulz, H. (ed.): Weißstorch im Aufwind? - White Storks on the up? Proceedings International Symposium on the White Stork, 26-29 September 1996, Hamburg. - NABU (Naturschutzbund Deutschland), Bonn.

Šoštarič, M. (1965): Štorklje v slovenskem Podravju in Pomurju. - Varstvo narave 4: 81-89.

Štumberger, B. (I990): Popis gnezdišč bele štorklje Ciconia ciconia v občini Ptuj v letu 1989. - Acrocephalus 11 (43/44): 11-18.

Tоме, D. (2006): Ekologija. Organizmi v prostoru in času. - Tehniška založba Slovenije, Ljubljana.

Tortosa, F.S. \& CASTro, F. (2003): Development of thermoregulatory ability during ontogeny in the White Stork Ciconia ciconia. - Ardeola 50 (1): 39-45.

Tortosa, F.S. \& Redondo, T. (I992): Motives for parental infanticide in White Storks Ciconia ciconia. - Ornis Scandinavica 23 (2): 185-189.

Tortosa, F.S., Máñez, M. \& Barcell, M. (1995): Wintering White Storks (Ciconia ciconia) in South West Spain in the years 1991 and 1992. - Vogelwarte 38: 41-45.

Tryanowsky, P., Kosicki, J.Z., Kuźniak, S. \& Sparks, T.H. (2009): Long-term changes and breeding success in relation to nesting structures used by the white stork, Ciconia ciconia. - Annales Zoologici Fennici 46: 34-38.

Vergara, P., Aguirre, J.I. \& Fernández-Cruz, M. (2007): Arrival date, age and breeding success in white stork Ciconia ciconia. - Journal of Avian Biology 38: 573-579.

Zwarts, L., Bijlsma, R.G., van Der Kamp, J.\& WyMEnga, E. (2009): Living on the Edge: Wetlands and Birds in a changing Sahel. - KNNV Publishing, Zeist.

Arrived / Prispelo: 7.12.2010

Accepted / Sprejeto: 22.6.2011 


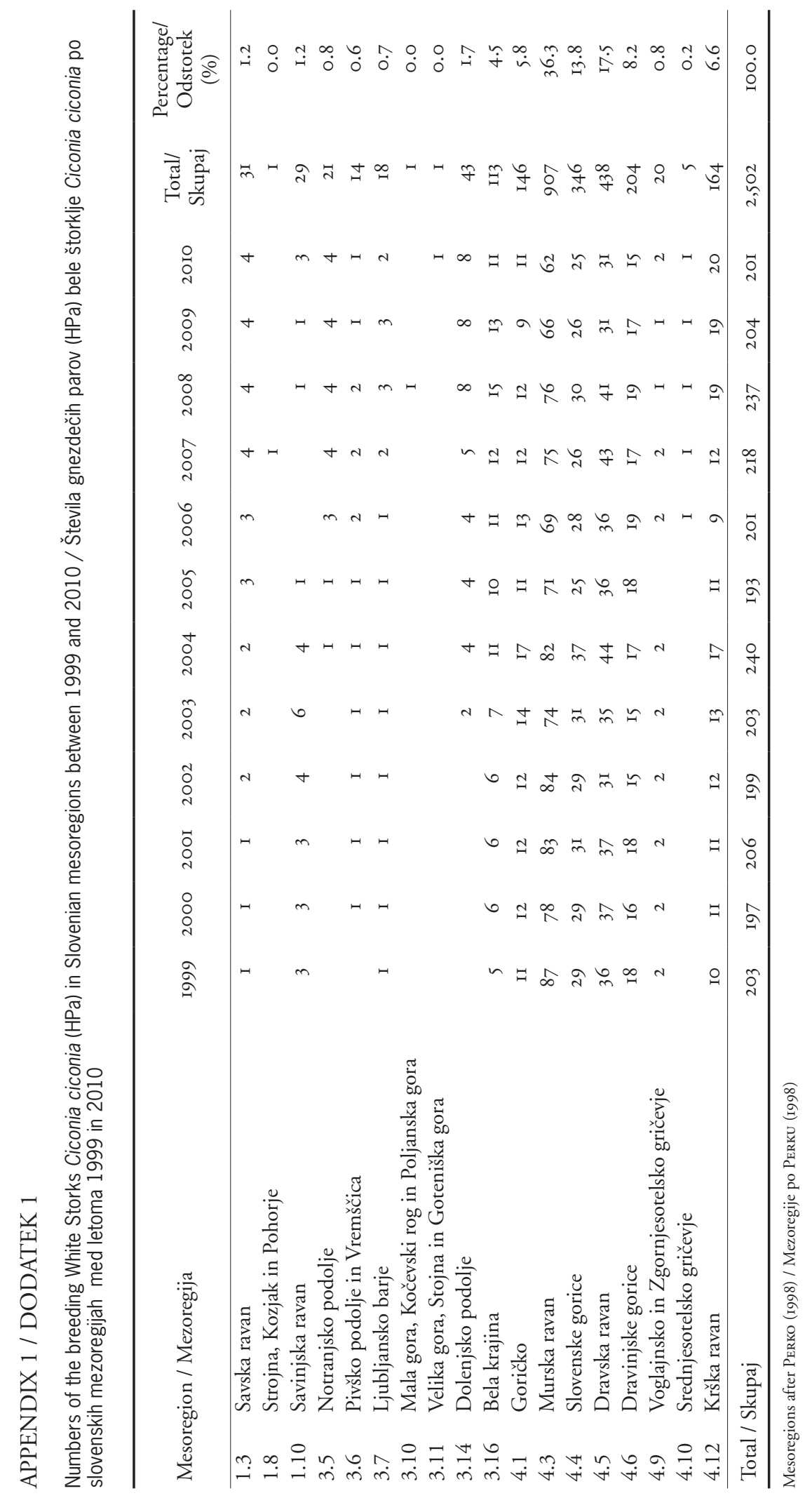




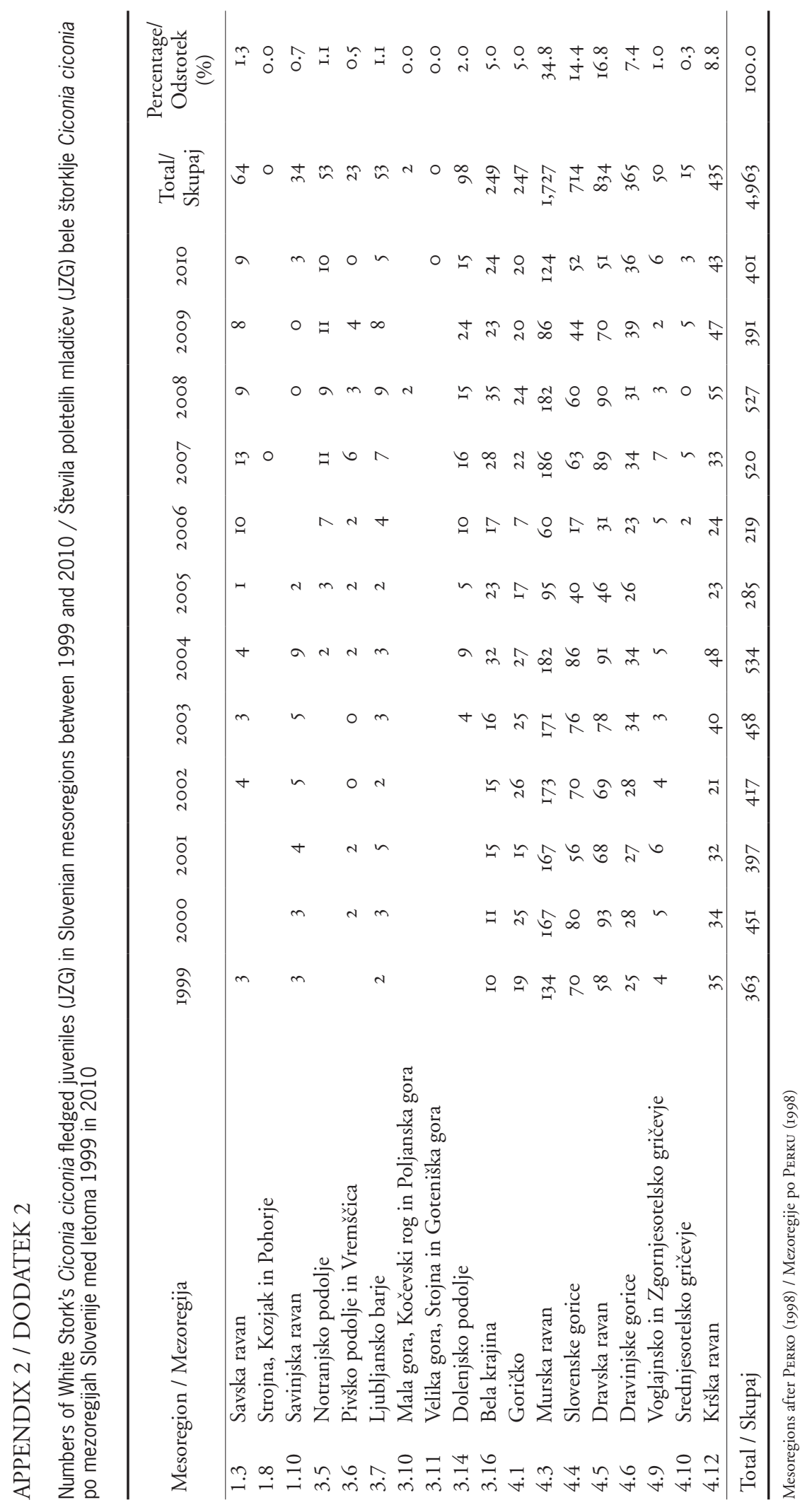




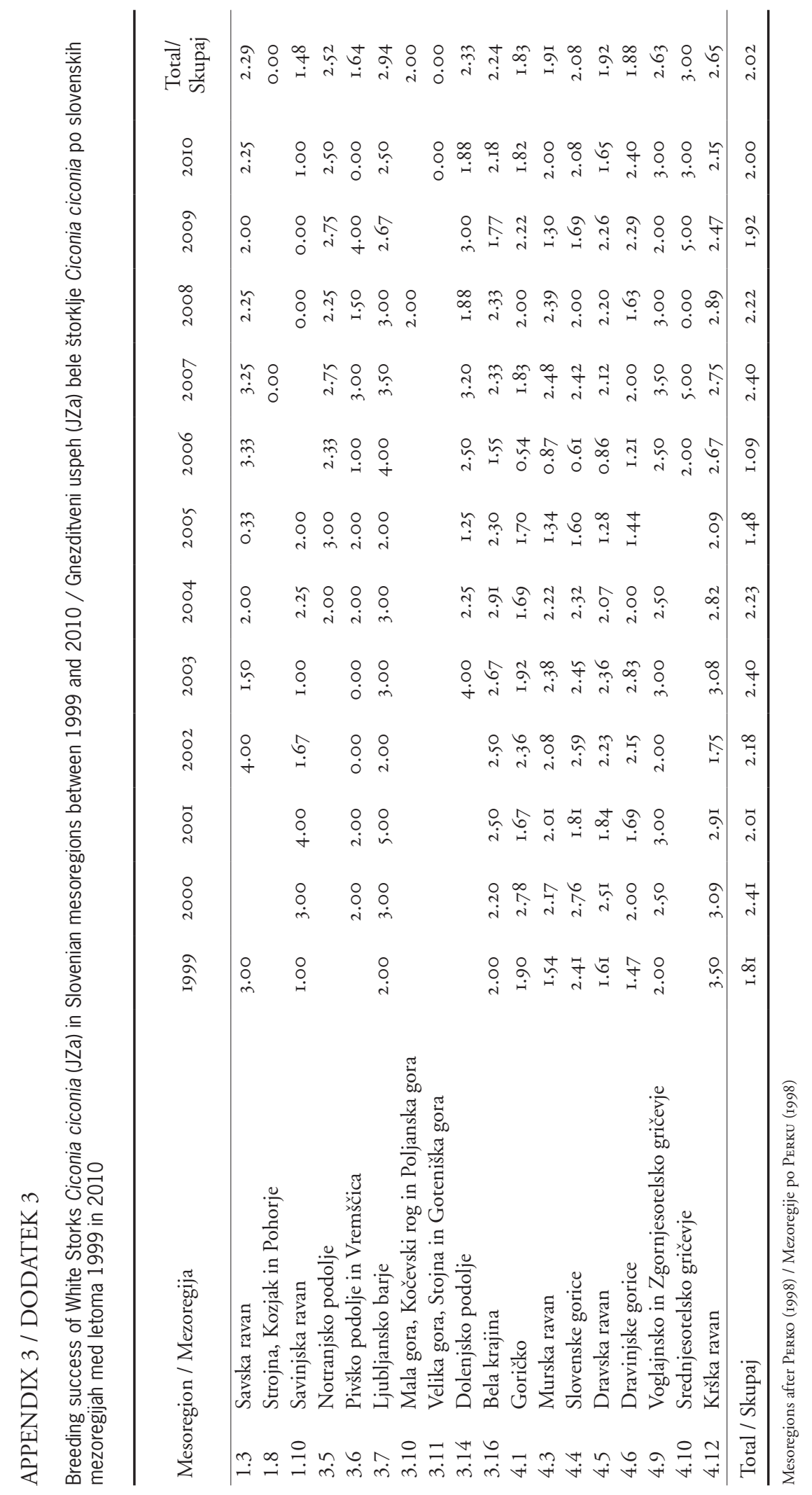




\section{APPENDIX 4 / DODATEK 4}

Mesoregions in Slovenia where White Stork Ciconia ciconia breeding pairs (HPa) were recorded between 1999 and 2010; mesoregions after PeRko (1998). For mesoregions names see Appendices 1, 2 \& 3. / Mezoregije Slovenije z gnezdečimi pari (HPa) bele štorklje Ciconia ciconia med letoma 1999 in 2010; meje mezoregij po PeRKU (1998). Za imena mezoregij glej dodatke 1,2 in 3.

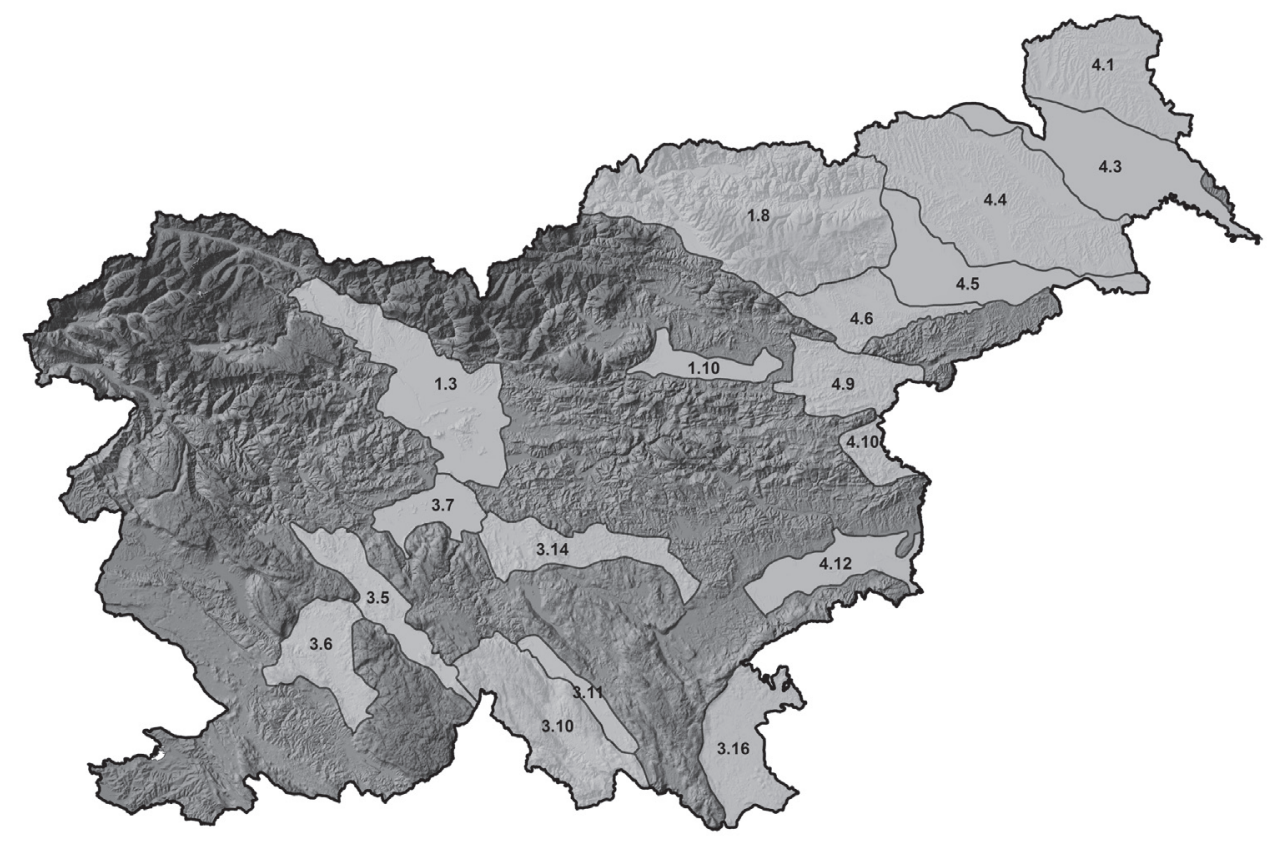

